\title{
Public Participation in Strategic Planning as a Basis for the Formation of Digital Technologies
}

\author{
Lvova M.I. Shvedov V.V. Sulimin V.V.
}

Ural State University of Economics, Yekaterinburg, Russia

Corresponding author.Email: lvova_usue@mail.ru

\begin{abstract}
This article examines the competitive regional development of territories through attracting and ensuring the active participation of one of the territorial subjects, which consist of members of civil society in the formation of strategic alternatives and market development. Modern problems of management and competitive regional development are formed firstly in territorial marketing, including interests of civil society as one of the subjects of marketing territorial space. This determines the efficiency of the system and is actively lobbied by the legal field of the Russian Federation, as evidenced by the analytical report within the legal field framework. Modern legal trends clearly determine the necessity for civil society to participate in the formation of strategic marketing initiatives, in strategic planning and therefore in marketing context of territorial development and ensuring competitive regional development of territories in modern Russia.
\end{abstract}

Keywords: strategic planning, competitive regional development, legal field, civil society, territorial subjects,

regional development

\section{INTRODUCTION}

One of the forms of strategic development of territories in modern economic system is territorial marketing. The issues of strategic promotion of territories, the growth of its investment attractiveness for a long time were considered from the perspective of attracting external investors, however, the practice of strategic planning led to necessity of taking into account interests of internal residents of the territory, primarily interests of civil society. Achieving maximum satisfaction of their needs allows us to ensure effective strategic planning for the development of territories in modern conditions, which fully corresponds with concept of territorial marketing.

Participation of civil society in strategic planning is the systematic interaction of society institutions and individual citizens in the process of strategic decision-making by the state authorities of the Russian Federation, the constituent entities of the Russian Federation, and local selfgovernment. Territorial marketing is aimed at the fullest satisfaction of economic interests of all subjects of the territory and participation of civil society as a representative of households within the territory is simply necessary.

The purpose of this study is to determine the legal preconditions for participation of the society as a subject of the territorial marketing system in formation of strategic planned alternatives.

Now we define the following research tasks:

- Definition of participation formats of a civil society, as a subject of territory in acceptance of government decisions;
- Identification of public participation problems in marketing strategic planning;

- Detection specifics of state policy in sphere of public participation in adoption of strategic territorial decisions;

- Definition of main organizational and legal forms of civil society participation in the territorial planning.

\section{MATERIAL AND METHODS}

The methods of research are an analytical, legal statistical and theoretical-empirical method. The criterion of the effectiveness of public participation in context of territorial marketing is situation in which problems voiced by the public are on a work agenda of government and local self-government. Public participation of territorial subjects in strategic planning is an essential element of strategic planning system at the federal and regional and local levels and ensures the effectiveness of marketing interaction. Strategic documents of state, regional and municipal levels should be considered not only as a management decision, but also as social contract of all subjects of the territory, which forms the basis of marketing platform. Thus, the participation of public institutions is the most important principle of strategic planning. In literature, public participation in the adoption of government decisions is usually considered in four aspects: as a tool to ensure the implementation of citizen's rights to 
participate in government control, as a way of informing citizens about processes of government decision-making, as well as a way to legitimize government decisions and, accordingly, a favorable attitude to management decisions of territories, effective development of territories, which forms the marketing concept. Historically, since the sixties of the last century, the management and economic sciences have paid attention to the participation of society in government management, particularly in the works of James Bückenen and Gordon Tallock [1].

The attention of scientists to various aspects of citizen participation in adoption of government decisions led to emergence of a separate direction of economic science the theory of public choice, which investigates various ways and methods of harmonizing the interests of society, individuals and government, which is now defined as a platform for territorial marketing. V.N. Vinogradov and O.V. Ehrlich consider that strategic plan is not one-way obligation of public authorities, but a dialogue between state authorities and local selfgovernment, population and enterprises [1].

Thus, problems of public participation in strategic planning require systematic monitoring and solutions in system of various subjects of territories.

Among the problems of public participation in marketing strategic planning for development of territories, the following can be singled out:

- Lack of public trust to authorities;

- Pessimism regarding the prospects for full implementation of strategic documents;

- Weak methodical qualification of population for participation in such events;

- Lack of clear understanding, regulation and organization of public participation procedures;

- Lack of coherence of interests of different population groups.

Constitutional and legal basis for participation of civil society institutions in adoption of government decisions is Article No.32 of the Russian Federation's Constitution concerning right of citizens to take part in government directly or through their representatives. Currently, the issues of public participation in government are given sufficient attention, which is reflected in government policy.

In particular, the Federal Law "Basics of Public Control in the Russian Federation" [4] was adopted, including, the description of forms and procedures for interaction between society and government. Other federal laws are devoted to public participation, including Federal Law No. 172-FZ "About strategic planning in the Russian Federation" [7]. All ways of public participation in government management can be classified according to the levels: national, regional and local.
Constitutional rights of citizens (national level) associated with participation of citizens in government management (rights to elect and be elected, to have equal access to public service, to participate in administration of justice, etc.). Municipal level is recorded in Federal Law № 131-FZ "General Principles of Organization of Local Self-Government in the Russian Federation" specifies the main forms of participation of population in addressing issues of local significance: referendum, law-making initiative of citizens, public hearings, survey of citizens etc.

Depending on the way of participation, it is distinguished direct participation (personally) or indirect (through representatives, non-profit organizations, etc.). Based on composition of subject, form of participation can be individual or collective. In scientific literature there are huge number of different classifications of ways and forms of citizen participation in government management.

Organizational and legal forms of citizens' participation in government management often have a collective form of interaction between citizens and state. In particular, the following organizational and legal forms are distinguished:

- Public chambers (federal, regional and municipal levels);

- Public organizations;

- Public initiatives;

- Youth parliaments;

- Non-profit organizations;

- Social movements, etc.

Special attention in numerous normative legal acts is given to public discussions, which are fixed in the Federal Law "Basics of Public Control in the Russian Federation" as a form of public control and corresponds to marketing consumerism concept.

There is a concept of public control in this law: activities of subjects of public control, connected to monitoring of public authority's activities, local governments, state and municipal organizations, other organizations that exercise certain public powers in accordance with federal laws, as well as for public inspection purposes, analysis and public evaluation of issued acts and taken decisions.

This conception can include historically developed forms of citizens' participation in government management, in particular public hearings and discussions. It should be mentioned that the law contains only an exemplary list of public control forms, however, based on paragraph 3, Article 18 of Federal Law №212 it should be accented that other types of public control in any case should be recorded in the legislation. Article 18 accents that public control can be performed simultaneously in several forms such as direct control and other types of interaction. Public discussion is understood by Federal Law "Basics of 
Public Control in the Russian Federation" as a public discussion of socially significant issues, as well as draft decisions of public authorities, local government, state and municipal organizations, other organizations that exercise certain public powers in accordance with federal laws, with mandatory participation in such discussions of authorized persons and organizations, representatives of citizens and public associations whose interests are affected by the relevant decision [5]. The form, timing and order of public discussion are established taking into account the features and level of the authority. Decree of the Government of the Russian Federation of December 30, 2016 No. 1559 [7] contains the procedure for implementing this form of public participation. The procedure for public discussion of draft strategic planning documents is held in the Federal Information System for Strategic Planning established to ensure the strategic planning process on all levels of government.

This system is connected to other information systems and resources that are sources of official information about processes occurring in the state (A united interdepartmental information and statistical system, a federal state information system for spatial planning, a state integrated information management system for public finances "Electronic Budget" and others, which necessary to support the adoption of managerial decisions in the area of public administration of systems). It should be mentioned that the practice of public participation in strategic planning in Russia, unfortunately, is point-based, sketchy and not systematic.

Despite quite a full regulatory and legal regulation of these processes, the population does not seek to take advantage of opportunities for participating in government management. In science and practice it is noted that the publicity of the development of strategic documents at all levels of government is declared in all cases, but the attitude of developers to the requirements of publicity is often formal.

Current situation calls for increased attention to the practice of public participation and requires investigation and implementation of the best practices in this area into the strategic planning of regional level.

Based on the results of monitoring the state of affairs in the sphere of strategic planning in Russia [9, p. 28], it is pointed that one of the problems is lack of the systematic practice of interaction in formation and implementation of strategic plans for regions and state authorities of subjects of the Russian Federation with business and non-profit organizations.

At the same time, according to the results of monitoring the implementation of Federal Law No. 172-FZ of June 28, 2014 "About strategic planning in the Russian Federation", fulfilled by the Institute of State and Municipal Administration of the National Research
University "Higher School of Economics" in 2016, it is noted that $90 \%$ of respondents consider it necessary to coordinate the goals of strategic development with companies in the real sector of the economy [9, p. 28]. Guided by the Article 13 of Federal Law No.172 regions create their own by-laws, which regulate the procedure for public participation in strategic planning of regions. [10, p. 29].

\section{RESULTS AND DISCUSSION}

Analysis of the practice of public institutions participation in strategic planning of regions made it possible to identify the forms of interaction that are most often realized within the framework of society participation in such processes.

Thus, the main form of participation of civil society institutions in strategic planning at the regional level is public councils and hearings. Public discussions, provided by the lawmaker as the main form of interaction between society and the government are realized through the availability of feedback via the Internet with representatives of non-profit organizations $(14 \%)$, as well as the examination of draft strategic documents by representatives of regional trade unions (4\%). Analyzing the effectiveness of civil society participation in strategic planning of the Sverdlovsk oblast, we note that in 2015, 6 meetings of the Public Council were held, in which, among others, public discussions were held on the draft plans for attracting investments in the economy of the Sverdlovsk region for 2015-2017.

Also, there was discussed the list of investment projects of strategic importance for social and economic development of the Sverdlovsk oblast, strategies for socio-economic development of the Sverdlovsk oblast up to 2030, draft strategy for development of social protection system of the Sverdlovsk oblast for 20162030. At the community boards under the Ministry of Economics of the Sverdlovsk oblast, social and economic development strategy of the Sverdlovsk oblast for the period until 2030 was discussed.

Thus, the most realizable in the Sverdlovsk oblast is public participation in strategic planning in form of public discussions [10, p. 31].

Information on long-term strategic planning in the Sverdlovsk oblast prepared for the Internet discussion, organized by the Committee of the Council of Federation of the Federal Assembly of the Russian Federation on the topic: Development of a system of long-term strategic planning at the federal, regional and local levels: the state, problems and tasks [2]. Among the flaws of strategic planning in the Sverdlovsk oblast at municipal level, there is non-involvement of the local 
structure and environmental uncertainty on

community, especially young people, into processes of public participation.

\section{CONCLUSION}

Summarizing the assessment of effectiveness of public participation in regional strategic planning, there are following important points:

- The importance of public participation to the authorities is obvious; - Opinion of civil society institutions is not the basis for the development of strategic documents, but it is objectively necessary for territorial marketing;

- Interaction of government and business is nonsystematic, therefore, government and business as subjects of territories should determine regular points of mutual achievement of economic interests, otherwise development of territorial marketing slows down and the efficiency of process decreases;

- There is an inability to clearly articulate and organize the participation of public institutions in strategic planning by state authorities of the Russian Federation, as well as public expectations and proposals for organizing interaction with public institutions, so the target audience of territorial marketing is not defined;

- Issues of regional government are ranked third among other issues in importance (after socioeconomic issues), issues of interaction between society and authorities are the least important, and this is marketing dissonance;

- Non-systematic interaction of strategic planning stakeholders is due to the absence of participants in strategic planning of economic entities from the real sector of economy in the Federal Law "About Strategic Planning in the Russian Federation".

\section{REFERENCES}

[1] Barak, S., \& Javanmard, S. (2020). Outsourcing modelling using a novel interval-valued fuzzy quantitative strategic planning matrix (QSPM) and multiple criteria decision-making (MCDMs). International Journal of Production Economics, 222 doi:10.1016/j.ijpe.2019.09.015

[2] Burt, G., \& Nair, A. K. (2020). Rigidities of imagination in scenario planning: Strategic foresight through 'Unlearning'. Technological Forecasting and Social Change, 153 doi:10.1016/j.techfore.2020.119927

[3] Chaib Lababidi, H., Lababidi, R., Colak, M., \& Dayan, M. (2020). Contingency effects of firm strategic planning process and firm performance: Evidence from UAE enterprises. Strategic Change, 29(2), 241-252. doi:10.1002/jsc. 2325

[4] Jaeckel, A. (2020). Strategic environmental planning for deep seabed mining in the area. Marine Policy, 114 doi:10.1016/j.marpol.2019.01.012

[5] Kaczor, C., Cole, J. W., Sapko, M. M., \& Kappeler, K. H. (2020). Realizing the vision for pediatric pharmacy practice advancement through strategic planning and implementation. American Journal of Health-System Pharmacy : AJHP : Official Journal of the American Society of HealthSystem Pharmacists, 77(6), 466-473. doi:10.1093/ajhp/zxz340

[6] Lee, J. G., \& Park, M. J. (2020). Evaluation of technological competence and operations efficiency in the defense industry: The strategic planning of south korea. Evaluation and Program Planning, doi:10.1016/j.evalprogplan.2019.101775

[7] Malekpour, S., Walker, W. E., de Haan, F. J., Frantzeskaki, N., \& Marchau, V. A. W. J. (2020). Bridging decision making under deep uncertainty (DMDU) and transition management (TM) to improve strategic planning for sustainable development. Environmental Science and Policy, 107, 158-167. doi:10.1016/j.envsci.2020.03.002

[8] Mwambo, F. M., Fürst, C., Nyarko, B. K., Borgemeister, C., \& Martius, C. (2020). Maize production and environmental costs: Resource evaluation and strategic land use planning for food security in northern ghana by means of coupled emergy and data envelopment analysis. Land use Policy, 95 doi:10.1016/j.landusepol.2020.104490

[9] Ojha, D., Patel, P. C., \& Sridharan, S. V. (2020). Dynamic strategic planning and firm competitive performance: A conceptualization and an empirical test. International Journal of Production Economics, 222 doi:10.1016/j.ijpe.2019.09.030

[10] Paucar-Caceres, A., Ribeiro dos Santos, P., Wright, G., \& Belderrain, M. C. N. (2020). Soft situational strategic planning (SSSP): A method and case study of its application in a brazilian municipality. Journal of the Operational Research Society, 71(3), 363-380. doi:10.1080/01605682.2019.1568840

[11] Stovba, E., Lukyanova, M., Stovba, A., \& Kolonskih, N. (2020). Foreign experience in the development of strategic planning theory and practice of sustainable development in rural areas on the foresight technologies basis. Paper 
presented at the IOP Conference Series: Materials Science and Engineering, , 753(7) doi:10.1088/1757-899X/753/7/072007 Retrieved from www.scopus.com

[12] Wang, J., Wu, Q., Yan, S., Guo, G., \& Peng, S. (2020). China's local governments breaking the land use planning quota: A strategic interaction perspective. Land use Policy, 92 doi:10.1016/j.landusepol.2019.104434. 